\title{
Karolina Drela
}

Uniwersytet Szczeciński

e-mail: karolina.drela@wzieu.pl

\section{ZMIANY DEMOGRAFICZNE A RYNEK PRACY W POLSCE \\ DEMOGRAPHIC CHANGES \\ VS. LABOUR MARKET IN POLAND}

DOI: $10.15611 /$ pn.2017.489.07

JEL Classification: J20, J11, J62, J21

Streszczenie: W artykule przedstawiono analizę liczby ludności i dostępności siły roboczej, zjawisko starzenia się i depopulacji w Polsce. Podjęto również próbę przedstawienia najważniejszych rozwiązań negatywnych zmian demograficznych na polskim rynku pracy oraz próbę określenia, czy można zminimalizować, zahamować albo odwrócić te tendencje. Większość państw wysoko rozwiniętych stoi obecnie wobec realnego kryzysu demograficznego związanego ze spadkiem liczby ludności (depopulacja) i starzeniem się społeczeństwa. W wyniku procesu starzenia zmieniają się relacje pomiędzy ludnością w wieku nieprodukcyjnym i produkcyjnym, wzrastają tzw. współczynniki obciążenia i ma to wpływ na polski rynek pracy, dlatego szczególną uwagę zwrócono na tempo zmian demograficznych i starzenia się, co pozwoliło autorce zaprezentować kilka rozwiązań tych problemów.

Słowa kluczowe: rynek pracy, bezrobocie, depopulizacja, starzenie się, tendencje demograficzne.

Summary: The article presents the analysis of number of population and the workforce availability, aging and depopulation in Poland. Also an attempt was made to show the most important solutions presented by the negative demographic trends on the Polish labour market, and an attempt to determine if it is possible to minimize, inhibit or reverse these tendencies. Most developed countries stand out against the real demographic crisis associated with a decrease in population (depopulation) and aging. As a result of aging the relationship between the aged non-productive and productive population changes, load factors increase and this has an impact on the Polish labour market. Therefore special attention was paid to the rates of population change and aging, which allowed the author to distinguish several solutions to these problems.

Keywords: labour market, unemployment, depopulation, aging, demographic trends. 


\section{Wstęp}

O tendencjach demograficznych zaczęło się szczególnie dużo mówić w Polsce w kontekście ujemnego przyrostu naturalnego, migracji i starzejącego się społeczeństwa. Wiadomo, że mają one znaczący wpływ na rynek pracy. Konsekwencji zmian demograficznych wpływających na rynek pracy upatrywać można między innymi w procesach depopulacji oraz procesach starzenia się ludności. Celem artykułu jest więc przedstawienie negatywnych konsekwencji tych dwóch procesów (w szczególności dla podaży pracy) oraz próba określenia, czy można zminimalizować, zahamować albo odwrócić te tendencje. $Z$ uwagi na ograniczenia objętościowe niniejszej publikacji, analiza zostanie zawężona jedynie do związku wybranych procesów demograficznych z rynkiem pracy - pominięto w szerszym aspekcie przyrost naturalny oraz ruch wędrówkowy ludności. Realizacja wskazanego wyżej celu badawczego jest oparta na źródłach danych zastanych. W analizie tych danych zastosowano metodę opisową i analizę danych zastanych.

\section{Procesy demograficzne}

Przemiany demograficzne, jakie można zaobserwować w Europie, dotyczą również Polski, która jest szóstym pod względem wielkości populacji krajem w Unii Europejskiej (UE), liczącym 38433000 mieszkańców [GUS 2017] na obszarze $312679 \mathrm{~km}^{2}$ i dziesiątym krajem UE pod względem gęstości zaludnienia [Chłoń-Domińczak i in. 2016, s. 4]. Podobnie jak inne kraje w Europie, charakteryzuje się niestety niską stopą urodzeń i rosnącą długością życia, co ma wpływ na piramidę wieku oraz prowadzi do starszej struktury w populacji.

Słusznie zauważył Andrzej Skibiński, że związek pomiędzy przeszłym i aktualnym przebiegiem procesów składających się na przyrost naturalny a przyszłymi strukturami ludności według wieku ma charakter sprzężenia zwrotnego i jest oczywisty, oraz że zarówno niska liczba urodzeń, jak i wydłużające się ludzkie życie przyczyniają się do intensyfikacji procesu starzenia populacji od dołu piramidy wieku (gdzie następuje malejący udział młodych osób) oraz od góry piramidy wieku (zauważa się rosnący udział osób starszych) [Skibiński 2016, s. 98-99].

Zbyt niska liczba urodzeń oraz wzrost liczby i odsetka osób starszych to zjawiska obserwowane w Polsce od kilkunastu lat. Mogą one powodować pewne trudności w rozwoju demograficznym w skali całego kraju, a także stanowić wielkie wyzwania dla polityki społeczno-gospodarczej w kontekście rynku pracy. Ze względu na wieloaspektowość zmian demograficznych postanowiono więc skupić uwagę na dwóch problemach: starzeniu się społeczeństwa i depopulacji.

\subsection{Starzenie się społeczeństwa}

Starzenie populacji jest zjawiskiem powszechnym i nieodwracalnym. Stopień zaawansowania procesu zależy od fazy rozwoju społeczeństwa. Zauważalne zmiany 
struktury populacji pojawiły się w XIX w. w Europie (Wielka Brytania, Francja, Dania, Szwecja) wraz z przemianami społeczno-ekonomicznymi związanymi z industrializacją i urbanizacją, którym towarzyszyły przemiany ludnościowe nazwane przejściem demograficznym ${ }^{1}$. W ciągu około 100 lat zjawisko rozprzestrzeniło się w całej Europie. Zmiany postaw i systemu wartości, zwłaszcza młodych ludzi, jakie dokonały się po II wojnie światowej, znalazły przełożenie w sferze zachowań demograficznych. W latach powojennych, a w zasadzie w latach 60 . XX w. rozpoczęły się przemiany nazwane II przejściem demograficznym, których cechą charakterystyczną były przeobrażenia m.in. w sferze formowania i rozpadu rodzin, opóźniania wieku wchodzenia w związki i rodzenia dzieci oraz intensywności tych procesów. Pod koniec stulecia zachowania specyficzne dla II przejścia demograficznego występowały w całej Europie. Znamienny jest fakt, że tam, gdzie rozpoczęły się najpóźniej, miały bardziej gwałtowny przebieg (np. kraje postkomunistyczne) [GUS 2014, s. 125].

Zgodnie z definicją starzenie się populacji oznacza zwiększanie odsetka osób starszych przy jednoczesnym zmniejszaniu odsetka dzieci. W literaturze jako metrykalny próg starości przyjmuje się najczęściej 60 (WHO) lub 65 lat (ONZ, Eurostat). Istnieje wiele miar i klasyfikacji stopnia zaawansowania starzenia społeczeństwa. Zgodnie z kryterium ONZ za starą uznaje się populację, w której udział ludności w wieku 65 lat i więcej przekracza 7\%. Odsetek powyżej 10\% oznacza fazę zaawansowanej starości [GUS 2014, s. 126].

Odsetek młodych ludzi (w wieku do 24 lat) w Polsce wynosił 26\% w 2015 r. Prognozy wskazują, że zmniejszy się do $24 \%$ do 2025 r. i do $20 \%$ do 2050 r., co oznacza, że nasileniu ulegnie proces starzenia się populacji, któremu towarzyszyć będzie starzenie się zasobów pracy.

Tabela 1. Ludność Polski na dzień 31 grudnia - prognozy

\begin{tabular}{|c|c||c|c||c|c||c|c|}
\hline Rok & Ludność & Rok & Ludność & Rok & Ludność & Rok & Ludność \\
\hline 2016 & 38369390 & 2028 & 37426538 & 2038 & 35999436 & 2046 & 34644715 \\
\hline 2020 & 38137804 & 2032 & 36917987 & 2042 & 35330941 & 2050 & 33950569 \\
\hline 2024 & 37833310 & 2034 & 36628362 & & &
\end{tabular}

Źródło: opracowanie na podstawie: http://stat.gov.pl/obszary-tematyczne/ludnosc/prognoza-ludnosci/ prognoza-ludnosci-na-lata-2014-2050-opracowana-2014-r-,1,5.html.

Według prognoz GUS w 2050 r. liczba ludności Polski wyniesie 33 mln 951 tys., co zaprezentowano w tabeli 1 . W porównaniu ze stanem na koniec 2013 r., który w prognozach był podawany jako rok bazowy, oznacza to zmniejszenie liczby ludności

\footnotetext{
${ }^{1}$ Proces charakteryzował się dużym zróżnicowaniem terytorialnym i czasowym - w różnym tempie następowała modernizacja społeczeństw europejskich, a populacje dokonywały przejścia od reprodukcji rozrzutnej [Okólski 2004] (wysokie natężenie urodzeń i zgonów) do reprodukcji oszczędnej (niski poziom umieralności i zgonów).
} 
o 4,55 miliona, czyli aż o $12 \%$. W tabeli 2 przedstawiono prognozy zmiany stanu ludności w Polsce.

Tabela 2. Zmiana stanu ludności w Polsce - prognozy

\begin{tabular}{|l|r|r|r|r|r|r|r|}
\hline \multicolumn{1}{|c|}{ Wiek/rok } & \multicolumn{1}{c|}{2015} & \multicolumn{1}{c|}{2020} & \multicolumn{1}{c|}{2025} & \multicolumn{1}{c|}{2030} & \multicolumn{1}{c|}{2035} & \multicolumn{1}{c|}{2040} & \multicolumn{1}{c|}{2045} \\
\hline Ogółem & -42746 & -281202 & -396342 & -556389 & -708302 & -808539 & -850847 \\
\hline $\begin{array}{l}\text { Przedproduk- } \\
\text { cyjny }\end{array}$ & -54269 & -143429 & -232422 & -569052 & -363463 & -305795 & -183338 \\
\hline Produkcyjny & -79010 & -589656 & -727396 & -197910 & -325511 & -563981 & -1336264 \\
\hline mobilny & -103084 & -945607 & -1277499 & -1180141 & -1036093 & -684367 & -384350 \\
\hline niemobilny & 24074 & 355951 & 550103 & 982231 & 710582 & 120386 & -951914 \\
\hline Poprodukcyjny & 90533 & 451883 & 563476 & 210573 & -19328 & 61237 & 668755 \\
\hline $0-14$ & -22954 & -69484 & -431739 & -371614 & -319408 & -234667 & -103889 \\
\hline $15-59$ & -279656 & -1300278 & -491954 & -554309 & -1015916 & -1423442 & -1653201 \\
\hline $60+$ & 259864 & 1088560 & 527351 & 369534 & 627022 & 849570 & 906243 \\
\hline $15-64$ & -225313 & -1334698 & -959942 & -642278 & -659320 & -1086454 & -1518934 \\
\hline $65+$ & 205521 & 1122980 & 995339 & 457503 & 270426 & 512582 & 771976 \\
\hline $75+$ & 30105 & 14369 & 645265 & 856772 & 702306 & 205328 & 84163 \\
\hline Kobiety 15-49 & -60287 & -335996 & -378517 & -638576 & -752466 & -585213 & -441569 \\
\hline
\end{tabular}

Legenda: wiek przedprodukcyjny: 0 do 17 lat, wiek produkcyjny: od 18 lat do wieku emerytalnego, wiek mobilny: od 18 do 44 lat, wiek niemobilny: od 45 lat do wieku emerytalnego, wiek poprodukcyjny: powyżej wieku emerytalnego.

Źródło: opracowanie na podstawie: http://stat.gov.pl/obszary-tematyczne/ludnosc/prognoza-ludnosci/ prognoza-ludnosci-na-lata-2014-2050-opracowana-2014-r-,1,5.html.

Kolorem szarym zaznaczono zwiększenie stanu ludności, gdzie np. osoby w wieku 65 lat i więcej będą stanowiły prawie $1 / 3$ populacji, a ich liczba wzrośnie o 5,4 miliona (w 2050 r.) w porównaniu z 2013 r. Z kolei kobiety w wieku rozrodczym w 2050 r. w będą stanowiły jedynie $62 \%$ stanu z roku wejściowego [GUS 2014, s. 109]. Zgodnie z przyjętymi założeniami, w okresie objętym prognozą przeciętne trwanie życia będzie nadal wydłużało się, osiągając w 2050 r. wartości większe od obecnie notowanych o 9 lat dla mężczyzn i 6 lat dla kobiet [GUS 2014, s. 121]. W perspektywie najbliższych dwudziestu kilku lat, z uwagi na gwałtowny proces starzenia się ludności wyrażony m.in. wzrostem udziału osób w zaawansowanym wieku, można spodziewać się także znacznego wzrostu liczby zgonów.

\subsection{Depopulacja}

Depopulacja oznacza proces wyludniania się pewnego obszaru, czyli zmniejszania się liczby ludności, a w rezultacie i gęstości zaludnienia tego obszaru. Z demograficznego punktu widzenia depopulacja jest rezultatem występowania - oddzielnie 
lub łącznie - dwóch czynników: ujemnego przyrostu naturalnego i ujemnego salda migracji. Spowodowana jest zatem nadwyżką zgonów nad urodzeniami albo/i nadwyżką emigrantów nad imigrantami. Wspomniane dwa czynniki z reguły oddziałują na siebie - to przede wszystkim ludzie młodzi skłonni są do przemieszczeń, zaś ich wyjazd przekłada się na zmniejszenie potencjału prokreacyjnego pozostałej ludności, co prowadzi do mniejszej liczby urodzeń przy mało zmienionej liczbie zgonów.

W warunkach depopulacji, która wynika z niedużej liczby urodzeń, jakość życia powinna wzrastać przede wszystkim z powodu możliwości szybkiego usamodzielnienia się ekonomicznego młodych ludzi, zgodnie z hipotezą Richarda A. Easterlina [Soja 2005]. Nadmiar osób młodych na rynku pracy negatywnie wpływa na ich pozycję zawodową z powodu większej konkurencyjności na rynku pracy, dodatkowo pogłębianej przez komplikacje w zastępowaniu starszych pracowników przez młodszych z powodu niedoskonałej ich substytucyjności, później osiągają stabilizację zawodową, a w efekcie później zakładają rodziny i posiadają mniej dzieci². W praktyce depopulacja pociąga za sobą zdecydowanie więcej negatywnych konsekwencji niż tych pozytywnych [Szukalski 2015, s. 3].

Reasumując, depopulacja to kolejny etap przejścia demograficznego charakterystycznego dla rozwiniętych państw, to zmniejszanie się liczby ludności, a spadek ten widoczny jest w młodszych grupach wiekowych. W związku z tym w społeczeństwach charakteryzujących się niską dzietnością występuje brak zastępowalności pracowników poddających się trwałej dezaktywizacji tymi rozpoczynającymi karierę zawodową - takie zjawisko zaczyna być widoczne również w Polsce. Zauważa się, iż rynek pracy w warunkach depopulacji jest rynkiem o niskiej stopie bezrobocia i wysokim poziomie płac, lecz w warunkach polskich założenie to nie jest do końca prawdziwe. Na niezmienionym poziomie powinien znajdować się popyt na pracę, lecz depopulacja prowadzi do zmniejszania się popytu na większość dóbr i usług, co przekłada się w przyszłości na spadek popytu na pracę. Wyludnianie związane jest również z problemami dotyczącymi pozyskiwania pracowników o szczególnych kwalifikacjach, gdyż w warunkach zmniejszania się liczby ludności (szczególnie dzieci i młodzieży) likwidowane są niektóre typy szkół, klas czy kierunki studiów, które dostarczają specjalistów w niszowych specjalnościach, a to ogranicza inwestycje kreujące nowe miejsca pracy ${ }^{3}$. Coraz więcej młodych ludzi migruje także w poszukiwaniu lepszej pracy za granicę.

\footnotetext{
${ }^{2}$ Niski relatywny udział młodych ludzi w populacji wpływa na ich lepszą pozycję materialną z powodu małej konkurencji na rynku pracy, gdzie relatywnie szybko powinni osiągać pozycję zawodową umożliwiającą podejmowanie długookresowych zobowiązań rodzinnych - a to do zwiększania płodności.

${ }^{3}$ Długookresowe trudności z pozyskiwaniem specjalistów narastają w sytuacji niskiego bezrobocia, albowiem wiele młodych osób nie widzi w takim przypadku potrzeby dłuższej edukacji, a to pogłębia problemy z rekrutacją na niszowe, a potrzebne kierunki i specjalności nauczania.
} 


\section{Rynek pracy}

Według prognoz GUS w nadchodzących latach Polskę czeka zdecydowany spadek liczby ludności. Przewiduje się, że do 2020 r. populacja zmniejszy się o ok. 360 tys. w porównaniu z 2013 r., do 2025 o ok. 755 tys., do 2030 prawie o 1,3 mln, a do 2050 o ponad 4,5 mln osób. Mimo wszystko w przypadku rynku pracy bardziej istotny od malejącej ogólnej liczby ludności okazuje się spadek liczby osób w wieku produkcyjnym.

Oczekuje się znacznego wzrostu liczby ludności emerytalnej, natomiast dolna część piramidy populacji wskazuje na malejącą populację młodych ludzi. Ten trend demograficzny ma bezpośredni wpływ na rynek pracy. Jeżeli rozpatrywać ludność w wieku produkcyjnym i poprodukcyjnym, to nastąpić ma wzrost ludności powyżej wieku emerytalnego o prawie $3 \mathrm{mln}$ osób i spadek o 5,5 mln w wieku produkcyjnym do 2050 r., co przedstawiono w tabeli 3.

Tabela 3. Ludność w Polsce - prognozy w mln osób

\begin{tabular}{|l|r|r|r|r|r|r|r|r|}
\hline \multicolumn{1}{|c|}{ Wiek/rok } & \multicolumn{1}{c|}{2013} & \multicolumn{1}{c|}{2020} & \multicolumn{1}{c|}{2025} & \multicolumn{1}{c|}{2030} & \multicolumn{1}{c|}{2035} & \multicolumn{1}{c|}{2040} & \multicolumn{1}{c|}{2045} & \multicolumn{1}{c|}{2050} \\
\hline Ogółem & \multicolumn{1}{c}{38,496} & 38,138 & 37,741 & 37,185 & 36,477 & 35,668 & 34,817 & 33,951 \\
\hline Przedprodukcyjny & 6,995 & 6,733 & 6,500 & 5,931 & 5,568 & 5,262 & 5,079 & 4,963 \\
\hline Produkcyjny & 24,548 & 23,820 & 23,093 & 22,895 & 22,569 & 22,005 & 20,669 & 19,048 \\
\hline mobilny & 15,338 & 14,219 & 12,942 & 11,762 & 10,725 & 10,041 & 9,657 & 9,331 \\
\hline niemobilny & 9,210 & 9,600 & 10,151 & 11,133 & 11,844 & 11,964 & 11,012 & 9,717 \\
\hline Poprodukcyjny & 6,952 & 7,584 & 8,148 & 8,359 & 8,340 & 8,401 & 9,070 & 9,939 \\
\hline
\end{tabular}

Źródło: opracowanie na podstawie: http://stat.gov.pl/obszary-tematyczne/ludnosc/prognoza-ludnosci/ prognoza-ludnosci-na-lata-2014-2050-opracowana-2014-r-,1,5.html.

Szczególne znaczenie z punktu widzenia rynku pracy ma kształtowanie się wewnętrznej struktury populacji osób w wieku produkcyjnym, czyli proporcji między ludnością w wieku mobilnym i niemobilnym. Liczba pracowników zaliczanych do tzW. wieku mobilnego, a więc między 18. i 44. rokiem życia, zmniejszy się od 2013 do 2020 r. o 1,119 mln i o 6 mln osób od 2013 do 2050 r. Z kolei w grupie pracowników tzw. niemobilnych, a więc w wieku 45-65 lat, zaobserwować będzie można wzrost o ponad 390 tys. osób (do 2020) i 0,5 mln osób do 2050 r. ${ }^{4}$

Do 2013 r. formalną granicę wieku produkcyjnego stanowiło 59 lat dla kobiet oraz 64 lata dla mężczyzn. W skali Polski w 2013 r. osoby w wieku 18-44 stanowiły większość ludności w wieku produkcyjnym, bo aż 62,5\% (37,5\% niemobilni).

${ }^{4} \mathrm{Z}$ punktu widzenia rynku pracy dużo większą wartość mają pracownicy zaliczani do grupy mobilnych. Wynika to z tego, że osoby te są zdolne do zmiany stanowiska, miejsca pracy czy ewentualnego przekwalifikowania. Pracownicy niemobilni to natomiast osoby, które nie są gotowe do zmiany miejsca pracy, dokształcania czy nawet przekwalifikowania w celu zmiany stanowiska pracy. 
Zaobserwować będzie można pogorszenie się liczebnej relacji między obydwoma populacjami, gdyż w 2020 r. osób w wieku produkcyjnym mobilnych będzie mniej, bo $59,7 \%$ (40,3\% niemobilnych), a w 2050 mniej (48,99\%) niż niemobilnych (51,01\%). Prognozuje się, że od 2032 r. ludności w wieku mobilnym będzie już mniej niż w wieku niemobilnym - wówczas osoby w wieku niemobilnym będą stanowiły aż $54,4 \%$ ogółu ludności w wieku produkcyjnym. Jak już wskazano, następne lata przyniosą niewielką poprawę tych zależności, by odsetek populacji niemobilnej zmniejszył się do $51,01 \%$ [GUS 2014, s. 150].

Współczynniki obciążenia demograficznego umożliwiają określenie stopnia nierównowagi w kształtowaniu się proporcji między grupami osób w wieku przedprodukcyjnym, produkcyjnym i poprodukcyjnym (tabela 4).

Tabela 4. Wskaźniki obciążenia demograficznego dla Polski - prognozy*

\begin{tabular}{|l|c|c|c|c|c|c|c|c|}
\hline Obciążenie ludnością w wieku/rok & 2013 & 2020 & 2025 & 2030 & 2035 & 2040 & 2045 & 2050 \\
\hline $\begin{array}{l}\text { Liczba ludności w wieku } \\
\text { poprodukcyjnym na 100 osób } \\
\text { w wieku produkcyjnym }\end{array}$ & 28 & 32 & 35 & 37 & 37 & 38 & 44 & 52 \\
\hline $\begin{array}{l}\text { Liczba ludności w wieku } \\
\text { nieprodukcyjnym na 100 osób } \\
\text { w wieku produkcyjnym }\end{array}$ & 57 & 60 & 63 & 62 & 62 & 62 & 68 & 78 \\
\hline $\begin{array}{l}\text { Liczba ludności w wieku } \\
\text { przedprodukcyjnym na 100 osób } \\
\text { w wieku produkcyjnym }\end{array}$ & 29 & 28 & 28 & 26 & 25 & 24 & 25 & 26 \\
\hline
\end{tabular}

* Według ustawy emerytalnej obowiązującej od 1.01.2013 r.

Źródło: opracowanie na podstawie: http://stat.gov.pl/obszary-tematyczne/ludnosc/prognoza-ludnosci/ prognoza-ludnosci-na-lata-2014-2050-opracowana-2014-r-,1,5.html.

Prognozowane zmiany w strukturze wiekowej wskazują na rosnący odsetek osób niepracujących do ludności w wieku produkcyjnym, głównie ze względu na rosnącą liczbę populacji w wieku emerytalnym. Ludność niepracująca wynosi obecnie 57\% populacji w wieku produkcyjnym, stanowiąc ok. $16 \mathrm{mln}$ osób, i przewiduje się, że wzrośnie ona do $63 \%$ i 78\% odpowiednio do 2025 i 2050 r. [Chłoń-Domińczak i in. 2016, s. 4], co wskazano w tabeli 4. W 2013 r. osoby w wieku przedprodukcyjnym i poprodukcyjnym stanowiły ponad $18 \%$ ogółu ludności. Pozostałe $63 \%$ to osoby W wieku produkcyjnym. W końcowym roku prognozy (2050) potencjalne zasoby pracy będą stanowiły $56 \%$ ludności, zaś istotna różnica wystąpi między populacjami w wieku nieprodukcyjnym, gdzie udział osób w wieku poprodukcyjnym będzie dwukrotnie większy niż w wieku przedprodukcyjnym.

Najgwałtowniejszy spadek zauważyć będzie można w grupie osób w wieku produkcyjnym mobilnym. Ekonomiści i demografowie przewidują, że w Polsce w latach 2013-2020 liczba takich osób spadnie o 7,3\%, a do 2050 o prawie 39,2\%. Co więcej, 
w ostatnich latach w wyniku zmiany liczby ludności i osób w wieku produkcyjnym nastąpił nieznaczny spadek udziału potencjalnych pracowników w ogólnej liczbie ludności. Z prognoz wynika, że ten negatywny trend będzie kontynuowany. Ostatecznie udział ten spadnie z poziomu 63,8\% w 2013 do 56,1\% w 2050 (do 62,5\% w 2030 r.), a więc o 7,7 p.p. (o 1,3 p.p. w 2020 r.). Natomiast udział potencjalnych pracowników w wieku mobilnym w ogólnej liczbie ludności również spadnie z poziomu 39,8\% w 2013 do 27,5\% w 2050 (do 37,3\% w 2030 r.), a więc aż o 12,3 p.p. (o 2,5 p.p. w 2020 r.), wzrośnie natomiast udział potencjalnych pracowników w wieku niemobilnym.

Zmieniająca się struktura oraz wielkość zasobów pracy prowadzi do stopniowego powstawania niedoborów na rynku pracy, na początku najczęściej przybierając charakter jakościowych niedoborów, które polegają na braku możliwości znalezienia odpowiednio wykwalifikowanych pracowników [Strzelecki 2012]. Wraz z pogłębianiem się niekorzystnych tendencji demograficznych obserwowane są także niedobory ilościowe jako ogólny brak wystarczająco licznej grupy chętnych oraz zdolnych do podejmowania zatrudnienia, niezależnie od dopasowania podaży pod względem poszukiwanej wiedzy i umiejętności. Wzrost liczby i udziału osób starszych oznacza zmiany w proporcji osób w wieku produkcyjnym i poprodukcyjnym, które mogą powodować niedostateczną podaż zasobów pracy [Lange 2008]. Taka sytuacja w oczywisty sposób negatywnie oddziałuje zarówno na kształt relacji rynku pracy, a także na poziom dobrobytu społecznego oraz tempo rozwoju gospodarczego państwa czy regionu. Rynek pracy będzie „czyszczony” wskutek wychodzenia z rynku pracy pokolenia powojennego wyżu demograficznego. Osoby, które są jeszcze na rynku, a urodziły się w latach 50., w naturalny sposób będą z niego wychodzić. W rezultacie zasoby pracy będą się zmniejszać. Analiza liczebności oraz struktury ludności według ekonomicznego kryterium stanowi potwierdzenie tezy o zaawansowanym starzeniu demograficznym zasobów pracy oraz wzroście liczby i odsetka populacji w wieku poprodukcyjnym. Występowanie wyżów i niżów demograficznych w przeszłości bardzo silnie oddziałuje na przewidywane wielkości (zwłaszcza osób w wieku niemobilnym i poprodukcyjnym) [GUS 2014, s. 148].

Zwrócić należy uwagę, że zaprezentowane informacje uwidoczniły niekorzystne procesy zachodzące w Polsce związane z malejącymi zasobami pracy. Konkludując, omawiane tendencje demograficzne spowodują i utrwalą:

- $\quad$ spadek liczby całej populacji w Polsce,

- wzrost długości trwania życia,

- $\quad$ spadek odsetka ludności w wieku produkcyjnym,

- spadek odsetka osób w wieku produkcyjnym mobilnym,

- wzrost odsetka osób w wieku produkcyjnym niemobilnym,

- $\quad$ spadek odsetka ludności młodszej (w wieku przedprodukcyjnym),

- wzrost odsetka ludności starszej (w wieku poprodukcyjnym),

- zjawisko depopulacji. 
W związku z tym wyróżnić powinno się zmiany, które zachodzą na rynku pracy i będą mieć kluczowe znaczenie zarówno dla funkcjonowania gospodarki, jak i tempa wzrostu PKB albo tempa wzrostu PKB per capita. Będą to zmiany w wielkości zasobów siły roboczej jako całości (nastąpi zmniejszenie liczby osób mogących podjąć pracę), a także ich kompozycji (m.in. zwiększenie odsetka pracowników w wieku przedemerytalnym). Zmiany proporcji grup wiekowych będą również przekładały się na zmiany w funkcjonowaniu rynku pracy, ponieważ potencjalni pracownicy z różnych grup wiekowych różnić się będą na przykład stopą uczestnictwa w rynku pracy [Janicka, Kaczmarczyk, Anacka 2015, s. 8]. Zmiany struktury wiekowej mogą mieć wpływ na poziom płac, a w związku z tym również na indywidualną podaż pracy. Zakłada się także niedopasowanie na rynku pracy w ujęciu sektorowym albo zawodowym, spowodowane depopulacją i starzeniem się społeczeństwa oraz zmianami w konsumpcji przez osoby starsze (np. w zakresie usług opiekuńczych, zdrowotnych, mieszkaniowych, transportowych i edukacyjnych ) i młode, a także zwiększeniem popytu na pracowników ochrony zdrowia oraz opieki, związane ze wzrostem liczebności populacji w wieku poprodukcyjnym. Decyzje o zmniejszeniu płodności i w związku z tym mniejsze obciążenie populacji ludźmi młodymi mogą przekładać się na wyższą aktywność zawodową, zwłaszcza kobiet. Natomiast jeżeli wydłużanie się życia związane będzie z poprawą zdrowia, to lepszy poziom zdrowia prawdopodobnie przekładać się będzie na wyższą produktywność, gdy sytuacja będzie odwrotna - na mniejszą produktywność. Wydłużanie życia może być również czynnikiem wypływającym na wydłużanie okresu pracy, by zwiększyć poziom oszczędności do wykorzystania na emeryturze. Kurczenie się zasobów pracy jako konsekwencja starzenia się pociągać będzie za sobą m.in. presję na wzrost płac, a to będzie zachęcało producentów do zmian $\mathrm{w}$ technologii produkcji i substytuowania pracy kapitałem.

\section{Zakończenie}

Przedstawione tendencje demograficzne wpływają negatywne na rynek pracy. Optymistycznym wariantem byłby wzrost i przyrost ludności, co wpłynęłoby na zwiększenie liczby ludności w wieku produkcyjnym w perspektywie czasu, a nie kontynuacja tendencji występujących obecnie, które zostały przedstawione wyżej. Należy podkreślić, że zmiany demograficzne znacząco wpływają na polski rynek pracy i są związane ze zmiennością poziomu oraz tendencji rozwojowych liczebności potencjalnych zasobów pracy, a także zmianą relacji między zbiorowością osób w wieku produkcyjnym a populacjami osób w wieku przedprodukcyjnym i poprodukcyjnym, zmniejszeniem bezrobocia, procesem starzenia się potencjalnych zasobów pracy [Kryńska 2011] i depopulacji.

Przeciwdziałanie skutkom omawianego przebiegu procesów ludnościowych powinno odbywać się dwutorowo. Z jednej strony mogą to być programy aktywizacyjne dla osób starszych oraz bezrobotnych i biernych zawodowo, również w odniesieniu 
do kobiet i niepełnosprawnych ${ }^{5}$. Drugie rozwiązanie należy znaleźć we wszelkich działaniach na rzecz zwiększania populacji osób w wieku produkcyjnym, w głównej mierze poprzez zachęty do zwiększania ilości posiadanych dzieci oraz migracji na dany obszar osób w wymaganym wieku bądź o odpowiednich kompetencjach, czyli w wyniku zastosowania tak zwanej migracji selektywnej czy imigracji.

W przypadku zmniejszających się zasobów pracy wskazane jest wykorzystanie wewnętrznych źródeł podaży pracy poprzez pobudzenie dotychczas niewykorzystanych zasobów wewnętrznych (przekwalifikowanie osób bezrobotnych, aktywizację zawodową biernych zawodowo, wykorzystanie wspomnianego wyżej kapitału ludzkiego starszych osób). Można tego dokonać, ale w bardzo długim okresie poprzez wydatkowanie na ten cel bardzo dużych środków finansowych, przygotowanie biernych zawodowo i bezrobotnych, by weszli na rynek pracy z pożądanymi kwalifikacjami, zwięessenie mobilności ludności wiejskiej oraz umożliwienie im nabycia kwalifikacji. Zwiększanie liczby pracujących młodych i starszych możliwe jest również przez wzrost poczucia bezpieczeństwa ekonomicznego, rozumianego jako realna szansa względnie łatwego podjęcia lub kontynuowania aktywności zarobkowej oraz możliwości osiągnięcia relatywnie wysokiego standardu życia, mierzonego jakością usług świadczonych przez szeroko rozumiany sektor publiczny: praca dla wszystkich osób zdolnych do pracy i gotowych do podjęcia zatrudnienia, w tym młodych i starszych osób, możliwość swobodnego wyboru zatrudnienia, zapewnienie prawa do korzystania ze świadczeń zabezpieczenia społecznego z tytułu wykonywania pracy i zapewnienie warunków pracy sprzyjających zachowaniu zdrowia, bezpieczeństwa pracy i godności pracownika oraz zagwarantowanie prawa do sprawiedliwego wynagrodzenia bez względu na wiek.

Zwiększenie aktywności zawodowej osób starszych nie tylko wspiera dochody i ogranicza wydatki budżetu państwa, ale również daje możliwość zabezpieczenia bieżących dochodów gospodarstw domowych i zwiększenia wysokości przyszłej emerytury ${ }^{6}$. Byłoby to możliwe dzięki odpowiedniej polityce zatrudnienia nastawionej na wspieranie zatrudnienia i przeciwdziałającej dyskryminacji osób starszych na rynku pracy (podczas poszukiwania zatrudnienia, jak i podczas wykonywania pracy) oraz dzięki systemowi ubezpieczeń społecznych, a w szczególności odpowiednio skonstruowanemu systemowi emerytalnemu [Wiśniewski (red.) 2009]. Trzeba również zastosować właściwe kwestie motywacji do pracy grupy osób w wieku poprodukcyjnym (np. źródła utrzymania oraz ich wysokość - m.in. rozwiązania systemu emerytalnego, zmiany kosztów utrzymania, pozazarobkowe formy uzyskiwania dochodów, takie jak tzw. odwrócony kredyt hipoteczny, praca jako źródło satysfakcji i podstawy godnej oraz autonomicznej starości, alternatywne sposoby spędzania

\footnotetext{
${ }^{5}$ Są to tzw. grupy defaworyzowane na rynku pracy, odznaczające się największą zdolnością mobilizacyjną, czyli stosunkowo dużą grupą osób, które mogłyby przejść ze stanu bierności zawodowej do czynnych zasobów pracy.

${ }^{6}$ Niska rewaloryzacja rent i emerytur spowodowała powrót $6 \%$ emerytów i rencistów na rynek pracy.
} 
czasu), a także ograniczyć czynniki potencjalnie zmniejszające możliwość zatrudnienia (tj. kwalifikacje zawodowe, w tym poziom wykształcenia, stan zdrowia, opieka nad członkami rodziny). Istnieje jednak obawa, że starsze generacje mogłyby stać się zbyt dużym obciążeniem dla młodszych, co mogłoby doprowadzić do napięć między tymi generacjami. Należałoby eliminować występujące bariery wejścia (powrotu) przez nich na rynek pracy, gdyż istotnym problemem w Polsce i na regionalnych rynkach pracy jest występujący ageizm, zwłaszcza wobec tej grupy populacji. Najlepszą drogą złagodzenia problemów wynikających ze starzenia się społeczeństwa i zachowania solidarności międzypokoleniowej jest dłuższe uczestnictwo starszych roczników na rynku pracy poprzez zachęcanie ich do późniejszego przechodzenia na świadczenie emerytalne oraz umożliwienie im jak najdłuższego okresu utrzymania dobrego stanu zdrowia, aktywności i niezależności.

W sytuacji niezmniejszającego się (lub wolniej niż podaż kroczącego) popytu na pracę możliwe jest również wyrównanie stanu nierównowagi poprzez uruchomienie zasobów zewnętrznych - imigrację. Drugą rezerwą podażową jest więc zmiana proporcji imigracji i emigracji. Zaproponowanie warunków korzystnych dla imigrantów i poprzez odpowiednie oferty pracy spowodować może zasilenie polskiego rynku pracy rodakami zza granicy (np. Kazachstan, Ukraina, Białoruś). Należałoby też zastosować narzędzia przyciągające migrantów zarobkowych, którzy wyjechali np. do UK czy Niemiec. Jest szansa, że w perspektywie kilkuletniej napływ do Polski osób w wieku produkcyjnym będzie większy od odpływu z polskiego rynku pracy.

Zwiększenie populacji osób w wieku produkcyjnym, ograniczające depopulację, wiąże się m.in. ze zmianami w postrzeganiu rodzin z dziećmi, w tym wielodzietnych. Czynniki, które mogą te trendy odwrócić, to m.in. czynniki psychospołeczne, kultura i sposób prezentowania poglądów na temat rodzin wielodzietnych w mass mediach, ustawianie wartości rodziny, zmiana poglądów na temat kariery kosztem rodziny i dzieci, wszelkiego typu rozwiązania pomagające w wychowaniu i edukacji dzieci (nie tylko program 500+), a w wieku szkolnym umożliwienie prawa do korzystania z poradnictwa, szkoleń zawodowych w celu pomocy w wyborze najbardziej odpowiedniego zawodu (w wieku mobilnym z kształcenia ustawicznego). To też dostępna profesjonalna opieka nad dzieckiem, wspieranie obecności młodych matek na rynku pracy oraz przeciwdziałanie całkowitemu wycofaniu się z niego jednego z rodziców poprzez odpowiednią alokację urlopów wychowawczych.

Przedstawione najważniejsze rozwiązania, które mogą zminimalizować, zahamować albo odwrócić skutki zaprezentowanych tendencji demograficznych na rynku pracy: starzenie się społeczeństwa i depopulację, autor pozostawia czytelnikowi pod rozwagę.

\section{Literatura}

Błędowski P., 2010, Aktywność zawodowa osób w starszym wieku, [w:] Kiełkowska M. (red.), Rynek pracy wobec zmian demograficznych, Zeszyty Demograficzne, nr 1, Instytut Obywatelski, Warszawa. 
Chłoń-Domińczak A. i in., 2016, Vocational education and training in Europe - Poland, Cedefop ReferNet VET in Europe reports, Warszawa, http://libserver.cedefop.europa.eu/vetelib/2016/2016 CR_PL.pdf (10.05.2017).

GUS, 2014, Prognoza ludności na lata 2014-2050, http://stat.gov.pl/obszary-tematyczne/ludnosc/prognoza-ludnosci/prognoza-ludnosci-na-lata-2014-2050-opracowana-2014-r-, 1,5.html (20.04.2017).

GUS, 2017, Ludność i ruch naturalny w 2016 r., http://stat.gov.pl/obszary-tematyczne/ludnosc/ludnosc/ludnosc-i-ruch-naturalny-w-2016-r-,30,1.html (20.05.2017).

Janicka A., Kaczmarczyk P., Anacka M., 2015, Zmiany zasobów pracy i ich ekonomiczne konsekwencje oraz inne ekonomiczne konsekwencje starzenia się populacji, Studia i Materiały, Ośrodek Badań nad Migracjami, Uniwersytet Warszawski, Warszawa.

Kryńska E., 2011, Gospodarcze aspekty wpływu zmian demograficznych na polski rynek pracy, Prace Naukowe Uniwersytetu Ekonomicznego we Wrocławiu, nr 168, tom 1. Ekonomia.

Lange M., 2008, Rynek pracy w obliczu starzenia się ludności Polski, [w:] Kowaleski J.T., Szukalski P. (red.), Starzenie się ludności Polski - między demografia a gerontologia społeczna, Wyd. UŁ, Łódź, s. 49-70.

Okólski M., 2004, Demografia. Podstawowe pojęcia, procesy i teorie w encyklopedycznym zarysie, Wydawnictwo Naukowe SCHOLAR, Warszawa.

Skibiński A., 2016, Uwarunkowania demograficzne rynku pracy na obszarze województwa śląkiego - wybrane aspekty, Studia Ekonomiczne. Zeszyty Naukowe Uniwersytetu Ekonomicznego w Katowicach, $\mathrm{nr} 258$.

Soja E., 2005, Hipoteza Easterlina w świetle zachowań prokreacyjnych generacji urodzonych w latach 1942-1966 w Polsce, Polskie Towarzystwo Ekonomiczne, Warszawa.

Strzelecki P., 2012, Czy Polska jest skazana na spadek podaży pracy w przyszłości? - wyniki analizy wrażliwości założeń prognoz dtugookresowych, Zeszyty Naukowe ISiD, nr 24.

Szukalski P., 2015, Demograficzno-społeczne konsekwencje depopulacji w województwie łódzkim, Problemy Społeczne, Polityka Społeczna w Regionie Łódzkim, nr 15.

Wiśniewski Z. (red.), 2009, Zarządzanie wiekiem w organizacjach wobec procesu starzenia się ludno$s ́ c i$, TNOiK Dom Organizatora, Toruń. 